\title{
Hyperferritinemia in the Chinese and Asian community: A retrospective review of the University of British Columbia experience
}

\author{
Paul R Yenson MD FRCPC ${ }^{1}$, Eric M Yoshida MD MHSC FRCPC ${ }^{2}$, Charles H Li MD FRCPC ${ }^{1}$, \\ Henry V Chung MD FRCPC ${ }^{3}$, Peter WK Tsang MD FRCPC ${ }^{1}$
}

PR Yenson, EM Yoshida, CH Li, HV Chung, PWK Tsang. Hyperferritinemia in the Chinese and Asian community: A retrospective review of the University of British Columbia experience. Can J Gastroenterol 2008;22(1):37-40.

BACKGROUND AND METHODS: Elevated serum ferritin is a common clinical finding. The etiology of hyperferritinemia in the Asia-Pacific population is less clear due to a low prevalence of known HFE mutations such as $\mathrm{C} 282 \mathrm{Y}$ and $\mathrm{H} 63 \mathrm{D}$, as well as an increased prevalence of viral hepatitis and hereditary anemia. A retrospective case review of 80 patients of Asian ethnicity referred to three subspecialists in tertiary care teaching hospitals between January 1997 and March 2005 for assessment of hyperferritinemia was performed.

RESULTS: Only four patients (5\%) had iron overload on liver biopsy or quantitative phlebotomy. Forty-nine patients (61\%) had secondary causes for their hyperferritinemia, of which 26 had liver disease; 16 of those patients also had viral hepatitis. Thirteen patients fulfilled criteria for the insulin resistance syndrome. Other causes included hematological disorders $(n=10)$, malignancy $(n=2)$ and inflammatory arthritis $(n=2)$. Twenty-seven cases $(34 \%)$ of unexplained hyperferritinemia were found. Of a total of 22 patients who underwent liver biopsy, significant iron deposition was found in one patient. Fifteen patients underwent C282Y and H63D genotyping, with two cases of H63D heterozygosity. Fourteen patients had first-degree relatives with hyperferritinemia. Three families were identified with more than two members affected, which is suggestive of a possible hereditary hyperferritinemia syndrome.

CONCLUSION: Secondary causes of elevated ferritin in the Asian population, particularly liver disease, are common, but primary iron overload syndromes appear to be rare. In a significant proportion of patients, the etiology remains unexplained. The genetic basis for hyperferritinemia in Asians is poorly defined and requires further study.

Key Words: Asian; Chinese; Ferritin; Hyperferritinemia; Iron
Hyperferritinémie dans la communauté chinoise et asiatique : Synthèse rétrospective de l'expérience britanno-colombienne

HISTORIQUE ET MÉTHODES : Un taux élevé de ferritine sérique est une observation clinique fréquente. L'étiologie de l'hyperferritinémie chez la population de l'Asie-Pacifique est moins claire en raison de la faible prévalence des mutations HFE, comme C282Y et H63D, et de la prévalence accrue de l'hépatite virale et de l'anémie héréditaire. Les auteurs ont procédé à une étude rétrospective regroupant 80 patients d'origine asiatique, adressés chez trois spécialistes dans des établissements universitaires de soins tertiaires entre janvier 1997 et mars 2005, pour une évaluation de leur hyperferritinémie.

RÉSULTATS : Seulement quatre patients (5\%) présentaient une surcharge ferrique à la biopsie hépatique ou à la phlébotomie quantitative. Chez quarante-neuf patients $(61 \%)$ on a trouvé une cause secondaire à leur hyperferritinémie; parmi eux, 26 souffraient d'une maladie du foie. Seize de ces patients étaient également porteurs d'une hépatite virale. Treize patients répondaient aux critères du syndrome d'insulinorésistance. Parmi les autres causes, mentionnons : troubles hématologiques $(\mathrm{n}=10)$, néoplasie $(\mathrm{n}=2)$ et arthrite inflammatoire $(\mathrm{n}=2)$. Vingt-sept cas $(34 \%)$ d'hyperferritinémie d'origine indéterminée ont été recensés. Sur 22 patients en tout, qui ont subi une biopsie hépatique, des dépôts significatifs de fer ont été découverts chez un seul patient. Quinze patients ont subi un génotypage du C282Y et de l'H63D et deux cas d'hétérozygotie H63D ont été relevés. Quatorze patients avaient des parents au premier degré atteints d'hyperferritinémie. On a recensé trois familles dont plus de deux membres étaient affectés, ce qui donne à penser que le syndrome d'hyperferritinémie pourrait avoir une composante héréditaire.

CONCLUSIONS : Les causes secondaires de l'élévation des taux de ferritine dans la population asiatique, particulièrement la maladie du foie, sont fréquentes, mais les syndromes de surcharge ferrique primaire semblent rares. Chez une proportion significative de patients, l'étiologie reste inexpliquée. Les fondements génétiques de l'hyperferritinémie chez les asiatiques est mal définie et devrait faire l'objet d'études plus approfondies.

clinical practice (3). In the Asia-Pacific population, with a low prevalence of known HFE mutations such as C282Y and H63D (4-8), the etiology of hyperferritinemia is more complex and less clear. Serum ferritin and transferrin saturations have been reported to be slightly higher in this population than in the Caucasian population (9), although the precise reasons for this are not clear. Secondary causes for hyperferritinemia in this population may include increased rates of viral hepatitis and hereditary anemias. Serum ferritin can also be elevated in ings include elevated ferritin and transferrin saturatio Isolated hyperferritinemia, however, is a common finding in

${ }^{1}$ Division of Hematology; ${ }^{2}$ Division of Gastroenterology, Department of Medicine, University of British Columbia, Vancouver; ${ }^{3}$ Department of Medicine, Royal Columbian Hospital, New Westminster, British Columbia

Correspondence and reprints: Dr Peter WK Tsang, Division of Hematology, Gordon and Leslie Diamond Health Care Centre, 10th Floor,

2775 Laurel Street, Vancouver, British Columbia V5Z 1M9. Telephone 604-875-4259, fax 604-875-4763, e-mail ptsang@bccancer.bc.ca Received for publication April 27, 2007. Accepted June 14, 2007 


\begin{tabular}{lc} 
TABLE 1 \\
Clinical and biochemical characteristics of Asian patients \\
referred to subspecialists for hyperferritinemia ( $\mathbf{n = 8 0})$ \\
\hline Age (at referral), years, mean (range) & $55(18$ to 80$)$ \\
Male, $\mathrm{n}(\%)$ & $53(66.3)$ \\
Female, $\mathrm{n}(\%)$ & $27(33.7)$ \\
Ethnicity, $\mathrm{n}(\%)$ & \\
Chinese & $66(82.5)$ \\
Japanese & $5(6.25)$ \\
Vietnamese & $5(6.25)$ \\
Filipino & $3(3.75)$ \\
Thai & $1(1.25)$ \\
Serum ferritin level, $\mu \mathrm{g} / \mathrm{L}$, mean (range) & $1099(351$ to >6000) \\
Transferrin saturation, \%, mean (range) & $60.1(8$ to 98$)$ \\
HFE genotyping, $\mathrm{n}$ & 15 \\
C282Y homozygote/heterozygote & 0 \\
$H 63 D$ heterozygote & 2 \\
$H 63 D$ homozygote & 0 \\
C282Y/H63D compound heterozygote & 0 \\
\hline
\end{tabular}

the settings of alcohol consumption, insulin resistance and inflammatory states.

With this in mind, we report our review of a series of patients of Asian ethnicity referred to three subspecialists in tertiary care teaching hospitals for assessment of hyperferritinemia. A significant proportion of these patients had isolated hyperferritinemia, in that they were completely asymptomatic with no clinical or biochemical evidence of iron overload or other secondary causes.

\section{Patients}

\section{PATIENTS AND METHODS}

The present study received approval from the Clinical Reseach Ethics Board at the University of British Columbia, Vancouver, British Columbia. A retrospective office chart review was performed on all patients of Asia-Pacific ethnicity (ie, Southeast Asian) who were referred to three tertiary care hospital-based subspecialists (one gastroenterologist and two hematologists) for assessment of hyperferritinemia between January 1997 and March 2005. For inclusion into the study, an elevated ferritin level was defined as a level greater than $200 \mu \mathrm{g} / \mathrm{L}$ in women and $300 \mu \mathrm{g} / \mathrm{L}$ in men.

\footnotetext{
Methods

Demographic data were collected on all patients. Patients underwent a clinical assessment by a subspecialist at the time of referral, including documentation of family history of liver disease or known hyperferritinemia; history of red blood cell transfusions, alcohol intake, iron supplementation and liver disease; as well as a physical examination. Baseline blood count, liver enzymes, serum iron level, total iron binding capacity and per cent saturation were determined. Elevated transferrin saturation was defined as greater than $0.45 \%$ in women and $0.50 \%$ in men. Hepatitis B virus (HBV) and hepatitis $\mathrm{C}$ virus (HCV) serology was performed if abnormalities in liver enzymes were found. Results of liver biopsy, stainable liver iron graded by the Tirmann-Schmelzer technique (10), hepatic iron concentration and quantitative phlebotomy (to achieve a serum ferritin level less than $50 \mu \mathrm{g} / \mathrm{L}$ ) were recorded, if performed.
}

\section{RESULTS}

A total of 80 consecutive patients (53 men and 27 women) were reviewed. Demographics are displayed in Table 1 . The majority of patients were of Chinese ethnicity $(n=66$, $82.5 \%)$. Japanese $(n=5,6.25 \%)$, Vietnamese $(n=5,6.25 \%)$, Filipino $(n=3,3.75 \%)$ and Thai patients $(n=1,1.25 \%)$ accounted for the remainder. Forty-nine patients $(61 \%)$ had alternate explanations for their hyperferritinemia. Twentyseven patients $(34 \%)$ had isolated and unexplained elevations in serum ferritin. Only four patients (5\%) had primary iron overload that was demonstrated on liver biopsy or quantitative phlebotomy. Twenty-two patients underwent liver biopsy, with significant iron deposition in one patient. An analysis for HFE mutations (C282Y, H63D) in 15 patients revealed only two cases of $H 63 \mathrm{D}$ heterozygosity.

In the four patients with primary iron overload, the mean serum ferritin level was $2444 \mu \mathrm{g} / \mathrm{L}$ (range $690 \mu \mathrm{g} / \mathrm{L}$ to $6000 \mu \mathrm{g} / \mathrm{L})$. Three patients required 21, 27 and 30 phlebotomies to achieve a serum ferritin level of less than $50 \mu \mathrm{g} / \mathrm{L}$. One patient had qualitative iron overload on liver biopsy with grade III iron deposition in hepatocytes and Kupffer cells. She was H63D heterozygous but could not tolerate therapeutic phlebotomy due to anemia. Three of these patients had a concomitant diagnosis of viral hepatitis $(\mathrm{HCV}, \mathrm{n}=2$; HBV, $\mathrm{n}=1$ ). One patient was H63D heterozygous.

Of the 49 patients with secondary causes, 26 had liver disease; the most predominant diagnosis was viral hepatitis in 16 patients (HBV, $n=7$; HCV, $n=8$; HBV and HCV coinfection, $n=1)$. Causes of nonviral liver disease included nonalcoholic steatohepatitis $(n=4)$, excessive alcohol intake $(n=3)$, Wilson's disease $(n=1)$, autoimmune hepatitis $(n=1)$ and undefined liver disease $(n=1)$. Hematological disorders were identified in 10 patients (thalassemia variants, $n=8$; myelodysplastic syndrome, $n=2$ ). Two patients had malignancies, and two had inflammatory arthritis (Figure 1). Thirteen patients had one or more features of the insulin resistance syndrome: body mass index greater than $25 \mathrm{~kg} / \mathrm{m}^{2}$, diabetes or hyperlipidemia. Ten patients had more than one identifiable cause. The mean serum ferritin level was $1135 \mu \mathrm{g} / \mathrm{L}$ (range $394 \mu \mathrm{g} / \mathrm{L}$ to $5277 \mu \mathrm{g} / \mathrm{L}$ ) but was higher in the viral hepatitis group (mean $1780 \mu \mathrm{g} / \mathrm{L}$, range $667 \mu \mathrm{g} / \mathrm{L}$ to $5277 \mu \mathrm{g} / \mathrm{L})$. Eighteen patients underwent liver biopsy, with eight showing no increase in stainable iron, and 10 showing grade I or II iron deposition. Quantitative iron assessment was performed in two patients, both with normal hepatic iron concentration (less than $25 \mu \mathrm{mol} / \mathrm{g}$ ). Eight patients were tested for HFE mutations (C282Y, H63D), with the lone finding of $H 63 D$ heterozygosity in a patient with insulin resistance syndrome. Seven patients underwent phlebotomy, with a mean of 8.4 treatments to achieve a serum ferritin level of less than $50 \mu \mathrm{g} / \mathrm{L}$. Twenty-one patients had elevated transferrin saturation.

A cause for hyperferritinemia was indeterminate in 27 patients. The majority of patients (26 of 27) had normal liver biochemistry. The mean ferritin level in this group was $811 \mu \mathrm{g} / \mathrm{L}$ (range $351 \mu \mathrm{g} / \mathrm{L}$ to $1747 \mu \mathrm{g} / \mathrm{L}$ ). One patient with abnormal liver biochemistry demonstrated on two occasions had normal transferrin saturation, and negative HBV and HCV serology. In five patients tested, no HFE mutations were found. Seven patients had elevated transferrin saturation - two patients underwent liver biopsy, which showed mild stainable iron, while the remaining patients underwent 


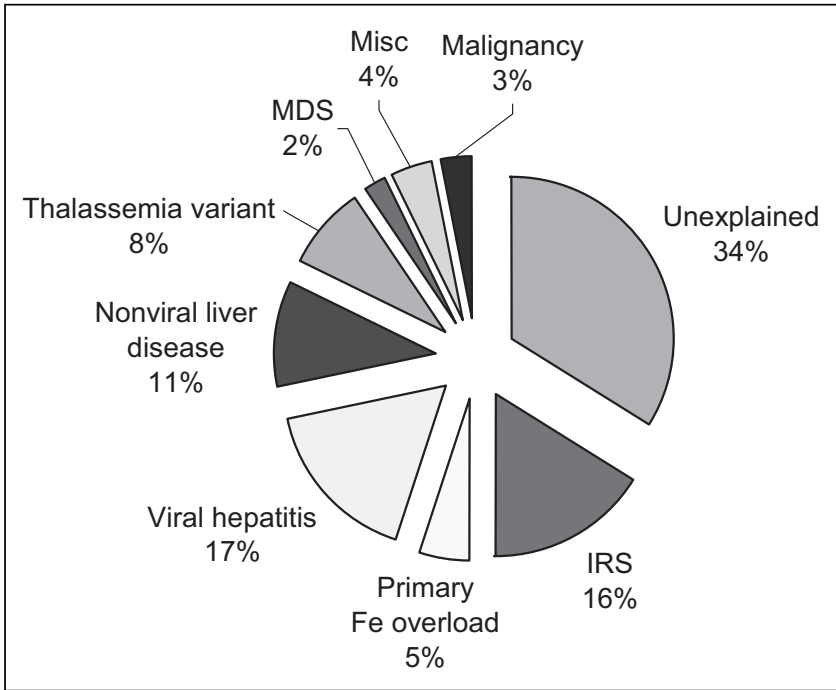

Figure 1) Etiology of hyperferritinemia in 80 Asian patients. Fe Iron; IRS Insulin resistance syndrome; Misc Miscellaneous; MDS Myelodysplastic syndrome

quantitative phlebotomy, all requiring fewer than eight phlebotomies (less than $2 \mathrm{~g}$ of elemental iron removed). A total of eight patients underwent a phlebotomy, with an average number of 6.6 treatments. In the entire cohort, 14 patients had first-degree relatives with hyperferritinemia, representing eight families. The genealogy of two of the three families that had more than two members affected is shown in Figure 2.

\section{DISCUSSION}

\section{Secondary causes}

In the present study, we described a series of patients of Asian descent who were referred to three tertiary care subspecialists for assessment of hyperferritinemia. Elevated serum ferritin is a common clinical finding. In the HEmochromatosis and IRon overload Screening (HEIRS) study (3), 101,168 primary care adults were screened for clinical, laboratory and genetic features of iron overload. Of 98,529 patients without a previous diagnosis of hereditary hemochromatosis or iron overload, 8652 (8.8\%) had elevated serum ferritin levels (greater than $400 \mu \mathrm{g} / \mathrm{L}$ in men and $300 \mu \mathrm{g} / \mathrm{L}$ in women). The prevalence of hyperferritinemia in participants of Asian background (mean \pm SD $19.00 \% \pm 0.35 \%)$ was higher than in the majority of other ethnic groups $(3,9)$.

A significant proportion of our patients had alternate explanations for elevated ferritin levels. Liver disease was found in a majority of these patients (26 of 49), with the most common diagnosis being viral hepatitis (16 of 49). This finding is consistent with both epidemiological data demonstrating the high prevalence of chronic HBV infection in Asian populations (11), as well as a documented association between chronic viral hepatitis and elevated serum markers of iron stores $(12,13)$. A similar study in a multiethnic population found that the majority of patients referred for elevated ferritin levels did not have HFE-linked hemochromatosis (14). Diagnoses of HBV and HCV were equally common in our study, likely reflecting the partial gastroenterology referral base in our study.

The mean ferritin level in our patients with viral hepatitis was $1780 \mu \mathrm{g} / \mathrm{L}$ (range $667 \mu \mathrm{g} / \mathrm{L}$ to $5277 \mu \mathrm{g} / \mathrm{L}$ ), which is higher

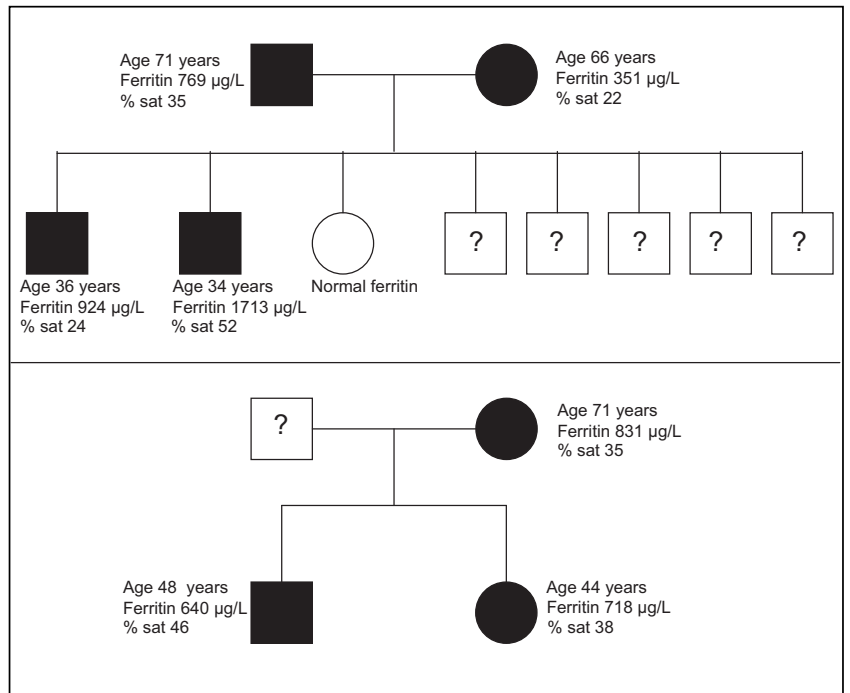

Figure 2) Pedigree of the elevated ferritin phenotype in two families (per cent saturation $[\% \mathrm{sat}]=$ transferrin saturation). Shaded squares (men) and circles (women) represent individuals who express elevated ferritin. Question marks indicate an unknown phenotype

than the mean ferritin levels reported in other studies $(12,15)$. None of our 12 patients with viral hepatitis who underwent liver biopsy had significantly elevated hepatic iron content by qualitative analysis, corroborating previous reports that elevated ferritin in the setting of chronic viral hepatitis does not correlate with hepatic iron stores (12).

Hyperferritinemia, in association with features of the metabolic syndrome, has been reported, although a causal link remains to be established $(16,17)$. This syndrome, dysmetabolic hyperferritinemia, is characterized by an elevated ferritin level, the insulin resistance syndrome (one or more of body mass index greater than $25 \mathrm{~kg} / \mathrm{m}^{2}$, diabetes or hyperlipidemia) and mild hepatic iron excess (18). Thirteen patients (16\%) fulfilled criteria for the insulin resistance syndrome.

\section{Primary iron overload}

In our series, true iron overload was suggested in four patients (5\%) by liver biopsy or quantitative phlebotomy. Three patients had a concomitant diagnosis of viral hepatitis ( HCV, $n=2 ; H B V, n=1)$, and the fourth patient had no other identifiable cause for iron overload. Her serum ferritin level was greater than $6000 \mu \mathrm{g} / \mathrm{L}$, and 30 phlebotomies $(7.5 \mathrm{~g}$ iron) were required to achieve a serum ferritin level of less than $50 \mu \mathrm{g} / \mathrm{L}$. Only $5 \%$ of the total liver biopsies (one of 22) demonstrated significant iron overload (Tirmann-Schmelzer method grade III or IV), compared with $36 \%$ of liver biopsies (52 of 146) in a similar multiethnic study (14). The present data appear to substantiate current evidence showing that primary iron overload syndromes are rare in Asians (19-21).

\section{Isolated hyperferritinemia}

In 27 patients, a secondary etiology was not found, despite an extensive assessment. In the small number of cases in which liver biopsy or quantitative phlebotomy was performed, the results were not consistent with significant hepatic iron excess (less than $2 \mathrm{~g}$ of iron removed to achieve a serum ferritin level of less than $50 \mu \mathrm{g} / \mathrm{L})$. HFE mutation analysis in this group revealed no $\mathrm{C} 282 \mathrm{Y}$ or $\mathrm{H} 63 \mathrm{D}$ alleles and two cases of $\mathrm{H} 63 \mathrm{D}$ 
heterozygosity overall, in keeping with epidemiological data, including the HEIRS study, showing the prevalence of HFE mutations to be exceedingly rare (3-8). Although a higher mean transferrin saturation has recently been reported in Asians (9), the majority of our unexplained cases had normal saturation, a pattern that can be seen in other conditions.

This group represents a novel cohort in which hyperferritinemia was not associated with symptoms or evidence of iron overload, ie, isolated hyperferritinemia. Several individuals had first-degree relatives with elevated ferritin, representing a potential hereditary hyperferritinemia syndrome. Two such families are portrayed in Figure 2. Ferroportin disease remains a diagnostic possibility, and rare cases of ferroportin mutations in Asian patients have been described (22,23). However, the true prevalence of non-HFE mutations in Asians is unknown, and testing is not routinely available.

\section{REFERENCES}

1. Simon M, Bourel M, Fauchet R, Genetet B. Association of HLAA3 and HLA-B14 antigens with idiopathic haemochromatosis. Gut $1976 ; 17: 332-4$

2. Feder JN, Gnirke A, Thomas W, et al. A novel MHC class I-like gene is mutated in patients with hereditary haemochromatosis. Nat Genet 1996;13:399-408.

3. Adams PC, Reboussin DM, Barton JC, et al, for the Hemochromatosis and Iron Overload Screening (HEIRS) Study Research Investigators. Hemochromatosis and iron-overload screening in a racially diverse population. $\mathrm{N}$ Engl J Med 2005;352:1769-78.

4. Merryweather-Clarke AT, Pointon JJ, Shearman JD, Robson KJ. Global prevalence of putative haemochromatosis mutations. J Med Genet 1997;34:275-8.

5. Hanson EH, Imperatore G, Burke W. HFE gene and hereditary hemochromatosis: A HuGE review. Human Genome Epidemiology. Am J Epidemiol 2001;154:193-206.

6. Mortimore M, Merryweather-Clarke AT, Robson KJ, Powell LW. The haemochromatosis gene: A global perspective and implications for the Asia-Pacific region. J Gastroenterol Hepatol 1999;14:838-43.

7. Chang JG, Liu TC, Lin SF. Rapid diagnosis of the HLA-H gene Cys 282 Tyr mutation in hemochromatosis by polymerase chain reaction - a very rare mutation in the Chinese population. Blood 1997;89:3492-3. (Lett)

8. Mah YH, Kao JH, Liu CJ, et al. Prevalence and clinical implications of HFE gene mutations (C282Y and H63D) in patients with chronic hepatitis $\mathrm{B}$ and $\mathrm{C}$ in Taiwan. Liver Int 2005;25:214-9

9. Harris EL, McLaren CE, Reboussin DM, et al. Serum ferritin and transferrin saturation in Asians and Pacific Islanders. Arch Intern Med 2007;167:722-6.

10. Brissot P, Bourel M, Herry D, et al. Assessment of liver iron content in 271 patients: A reevaluation of direct and indirect methods. Gastroenterology 1981;80:557-65.

11. Merican I, Guan R, Amarapuka D, et al. Chronic hepatitis B virus infection in Asian countries. J Gastroenterol Hepatol 2000;15:1356-61.

\section{CONCLUSIONS}

Our data suggest that, in referral populations, alternative explanations for hyperferritinemia are common in Asians, but primary iron overload syndromes are rare. The evaluation of these patients should include assessments for occult viral hepatitis and features of the metabolic syndrome. HFE mutations are rare in this population, and testing for these alleles is seldom useful. Regardless, in a significant proportion of Asian patients with hyperferritinemia, the etiology remains unexplained, with a suggestion of a familial basis in some cases. This may represent a hereditary hyperferritinemia syndrome specific to the Asian population. Ferroportin mutation analysis, which is not commercially available in British Columbia, may be helpful in the future, but the genetic causes of isolated hyperferritinemia, as well as underlying iron overload disorders in Asians, remain poorly defined and require further study.

12. DiBisceglie AM, Axiotis CA, Hoofnagle JH, Bacon BR. Measurements of iron status in patients with chronic hepatitis. Gastroenterology 1992;102:2108-13.

13. Riggio $\mathrm{O}$, Montagnese F, Fiore P, et al. Iron overload in patients with chronic viral hepatitis: How common is it? Am J Gastroenterol 1997;92:1298-301.

14. Wong K, Adams PC. The diversity of liver diseases among outpatient referrals for an elevated serum ferritin. Can J Gastroenterol 2006;20:467-70.

15. D'Souza RF, Feakins R, Mears L, Sabin CA, Foster GR. Relationship between serum ferritin, hepatic iron staining, diabetes mellitus and fibrosis progression in patients with chronic hepatitis C. Aliment Pharmacol Ther 2005;21:519-24.

16. Moirand R, Mortaji AM, Loreal O, Paillard F, Brissot P, Deugnier Y. A new syndrome of liver iron overload with normal transferrin saturation. Lancet 1997;349:95-7.

17. Wrede CE, Buettner R, Bollheimer LC, Scholmerich J, Palitzsch KD, Hellerbrand C. Association between serum ferritin and the insulin resistance syndrome in a representative population. Eur J Endocrinol 2006;154:333-40.

18. Mendler MH, Turlin B, Moirand R, et al. Insulin resistance-associated hepatic iron overload. Gastroenterology 1999;117:1155-63.

19. Kng C, Ng FH, Ng WF, et al. A Chinese patient with non-HFElinked iron overload. J Clin Gastroenterol 2001;33:69-71.

20. Hayashi H, Wakusawa S, Motonishi S, et al. Genetic background of primary iron overload syndromes in Japan. Intern Med 2006;45:1107-11.

21. Tsui WM, Lam PW, Lee KC, et al. The C282Y mutation of the HFE gene is not found in Chinese haemochromatotic patients: Multicentre retrospective study. Hong Kong Med J 2000;6:153-8.

22. Hayashi H, Wakusawa S, Motonishi S, et al. Genetic background of primary iron overload syndromes in Japan. Intern Med 2006;45:1107-11.

23. Jouanolle AM, Douabin-Gicquel V, Halimi C, et al. Novel mutation in ferroportin 1 gene is associated with autosomal dominant iron overload. J Hepatol 2003;39:286-9. 


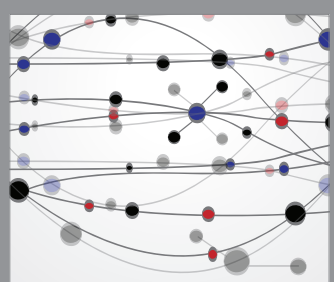

The Scientific World Journal
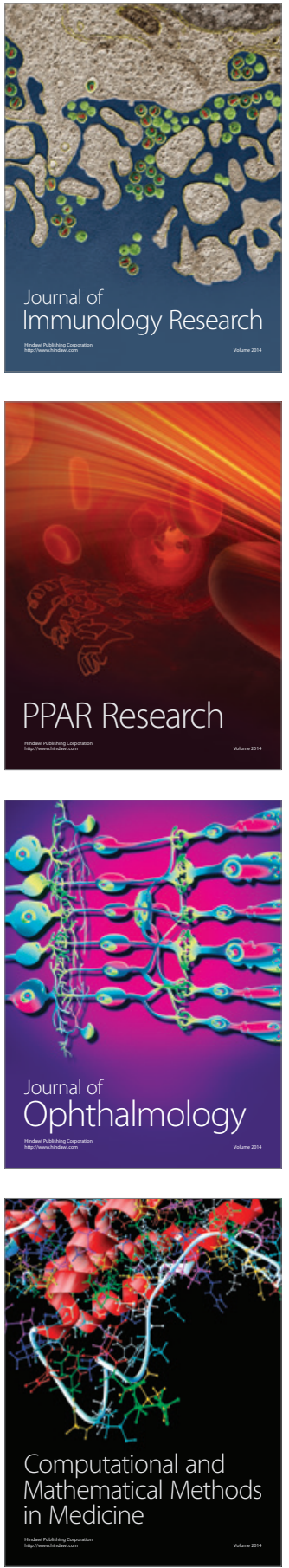

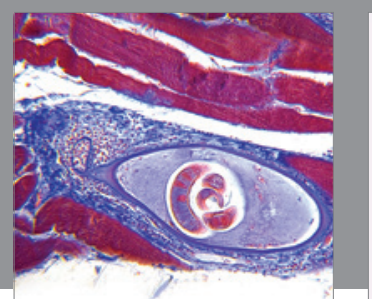

Gastroenterology Research and Practice

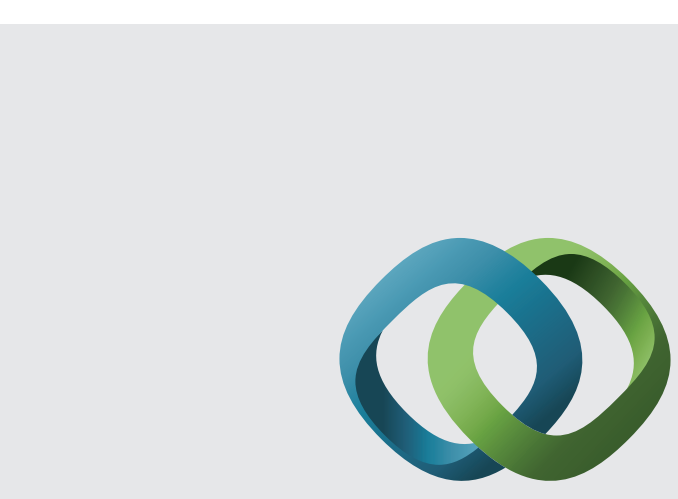

\section{Hindawi}

Submit your manuscripts at

http://www.hindawi.com
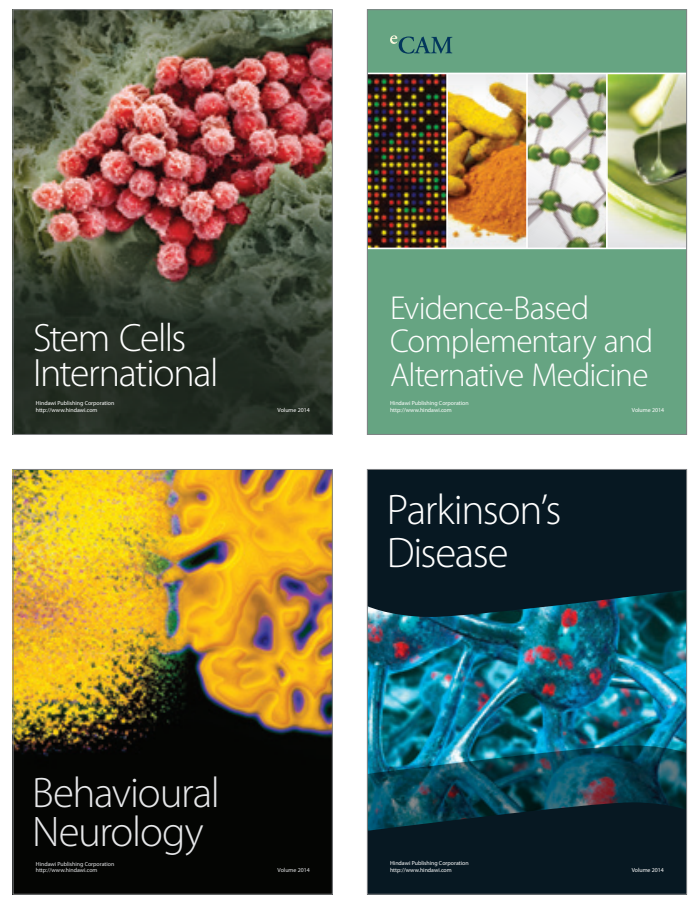
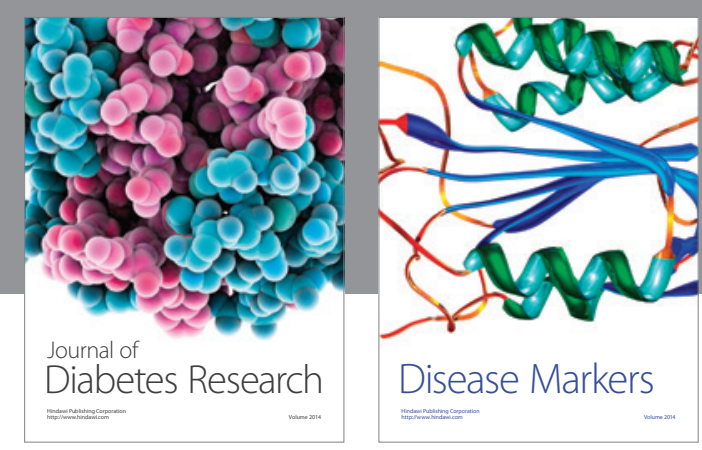

Disease Markers
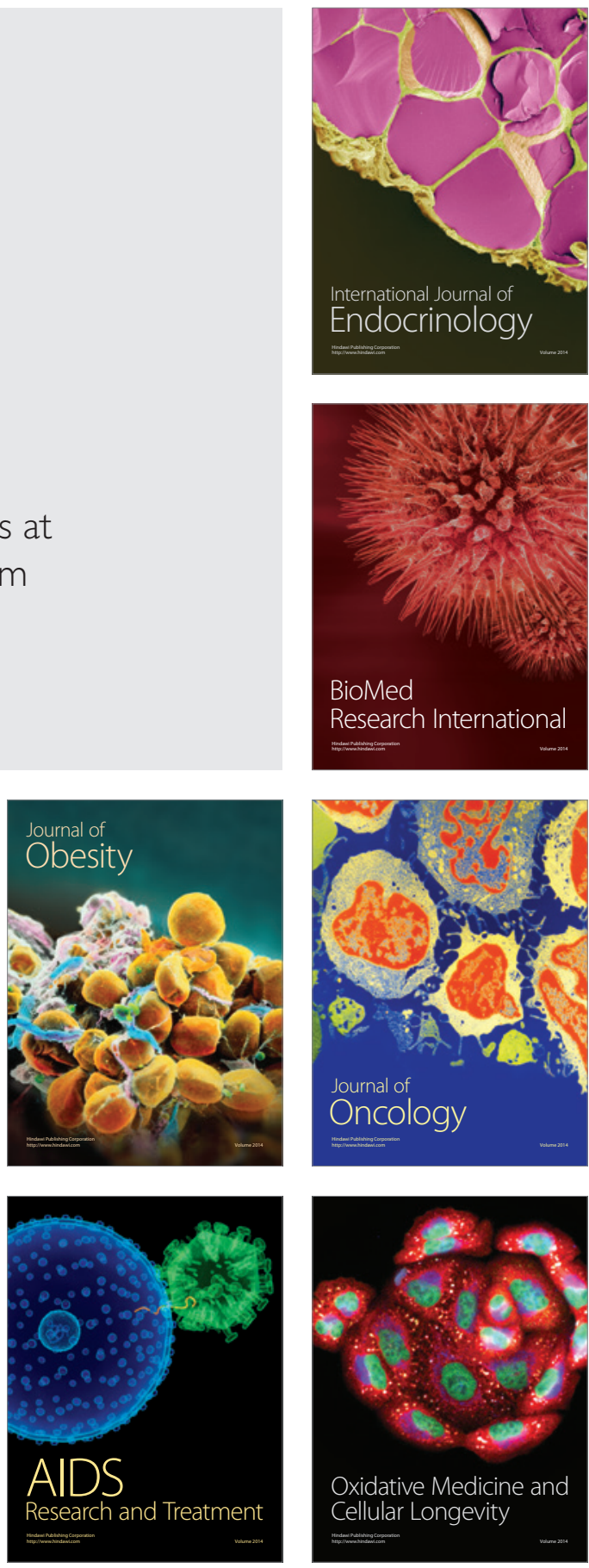